\title{
Krasztev Péter \\ EMLÉKEK EGY VÁROSRÓL ÉS EGY VÁROS EMLÉKEZETE \\ - a szabadnapos antropológus feljegyzéseiből -
}

$\underline{\text { DOI } 10.35402 / \text { kek.2020.4.8 }}$

\begin{abstract}
Absztrakt
Az esszé abból az alkalomból született, hogy 2019-ben Bulgária második legnagyobb városa, Plovdiv nyerte el az Európa Kulturális Fővárosa címet. Az esemény szervezői a balkáni multikulturális város vélt, vagy valós történelmi emlékei köré próbálják felépíteni a rendezvénysorozat koncepcióját. A szerző saját gyerekkori élményeit vetíti rá azokra a történelmi képzetekre, melyeket napjaink emlékezpolitikája igyekszik feléleszteni a város múltjával kapcsolatban. A bemutatott történelmi források példája az illusztrálja, hogy a „hagyománytermelés" nem csupán a mi korunk sajátja, ugyanakkor viszont a hagyaték, vagyis a minden történelmi törésen átöröklődő kulturális mintázatok rendületlenül felbukkannak egy város hétköznapi működésében.
\end{abstract}

\section{Abstract}

A town remembered, and a town's memories - notes of the anthropologist on leave -

This essay was inspired by the fact that Plovdiv, the second largest town in Bulgaria was chosen as European Capital of Culture in 2019. The organisers of the festivities made efforts to frame their concept in the real or fictitious notion of the Balkan multicultural city. The author of this essay projects his own childhood-memories on the historical idea on which the most recent Plovdiv (and Bulgaria in general) - related rememberancepolitics is based. By presenting a number of historical souces and evidences the essay illustrates that active production of tradition is not exclusively characteristic of our time only. Cultural patterns of historical legacy constantly manifest themselves in the wide scope of everyday operations of a city, and are inherited through time despite massive (and violent) ruptures in the historical process.

\section{Emlékezet és születés}

Akár a szülővárosom is lehetne. Állítólag csak egy véletlenen múlt. Ráadásul mi számít szülővárosnak: a hely, ahol az események, körülmények, a szülők pillanatnyi szeszélye folytán az ember a világra jön, vagy ahol először érzékelni kezdi az én és nem-én közti határvonalat. Plovdivhoz kötnek az első emlékeim, életem első tizenkét éve, ezért soha többé nem tudtam úgy visszatérni oda, hogy a jelent ne a múlt, saját múltam hosszan elnyúló árnyékaként lássam: a városhoz füződő minden későbbi élményem és történetem ennek a gyerekkornak a képeihez és érzeteihez igazodik, ezekhez viszonyítva értelmeztem minden újdonságot és változást. Ebben semmi érzelmeskedés nincs: az emlékezet a legnagyobb manipulátor - amint azt Yuval Harari eléggé meggyőzően összefoglalja a Homo Deus című könyvében -, evolúciósan és fiziológiailag a Homo Sapiens úgy fejlődött ki, hogy az emlékezet az ember szellemi integritásának legfőbb kapuőrévé vált, mely semmilyen cseltől nem riad vissza, ha a megfelelő mederbe akarja terelni az emlékek folyamát, vagy akár átszabni őket a későbbi élmények, tapasztalások fazonjához. Nem annyira maguk az emlékek, mint az emlékek emléke él bennünk, esetleges, célirányos parafrázisok formájában: jobb híján ebből építkezünk. És a mechanizmus tényleg működik - a gyerekkori, plovdivi emlékeim konstruáltak olyanná, amilyen később lettem, viszonzásként kinevezhetem a várost szülőhelyemnek, hiába nem ott pecsételték le a születési anyakönyvemet. Ugyanakkor Plovdiv, a maga több százszor megszakított, és ugyanennyiszer újraindított történelmével mintha amúgy is megtörné a róla szóló emlékeket, ezekből a megtört emlékekből újabb és újabb narratívákat és legendákat generál maga körül, mintha hagyná, hogy a különböző korokban élt emlékezők és történetírók ne egy várost, hanem saját ábrándjaik beteljesedését, vagy meghiúsulását lássák benne. Plovdiv maga úgy működik, mint egyfajta dinamikus és csapongó emlékezet, mely védelmezi saját szellemi integritását. 
$\mathrm{Az}$ apró és esetleges emlékeimről szeretnék itt írni, melyek talán átértelmezik mások emlékeit.

Az 1960-as évek közepétől a kontinens, de talán a világ egyik legszebb utcájában laktunk: a 20. század első évtizedeiben épült ki, ezzel kötötték öszsze a semmi közepén épült vasútállomást a Marica folyótól induló promenád túlvégével. Később ezen a csomóponton alakult ki a szocialista nagyváros központja, melyet gyerekkoromban Vörös térnek hívták, mivel itt zajlottak az államszocialista hitélet rejtett és látványos szertartásai: ide húzták fel a pártházat és itt érték el csúcspontjukat az ünnepi felvonulások. Az Ivan Vazov klasszikus íróról elnevezett, nyílegyenes sugárút az európai típusú várostervezés remekművévé ért a hatvanas évek közepén: az úttest két oldalára ültetett platánok elérték életciklusuk zenitjét, terebélyes koronájuk összeért az utca fölött, a lombok magasan a macskaköves burkolat fölött hatalmas, zöld alagutat formáztak. A látvány teljesen elfeledtette azt a körülményt, hogy a fatörzsek mögött eklektikus homlokzatú épületek sorakoznak, némelyek alagsorában lepukkant boltok kínálják szánalmas, államszocialista árukészletüket, de volt ott kórház és rendelőintézet, rendőrség, két iskola, városi könyvtár, szovjet konzulátus, sőt, középtájon erre a csodára ontották a dohánygyári szárítók ventilátorai a nyers dohány kesernyés illatát. Itt le lehetett volna élni egy életet úgy, hogy az ember még a mellékutcákba se sétál át, volt minden, amire szükség adódhat, és szép is volt, a legszebb, mert, nyilván, így rögzült gyerekkorom emlékeiben.

Beleszületni viszont túlzás lett volna ebbe a szépségbe. Anyám legalábbis így gondolta, ezt mesélte később. Egyszer megálltam a városi szülészet előtt, és belehallgattam az összeverődött tömeg beszélgetéseibe. Idegen nyelveken beszéltek, egy szót sem értettem belőle. Főleg férfiak álltak a háromszintes épület előtt, az előkert kerítésének rácsaiba csimpaszkodtak, az ablakokból pedig hálóinges aszszonyok kiabáltak nekik valamit, némelyek újszülötteket emeltek üdvözült mosollyal az arcuk elé, úgy sipítoztak valamit. Egyszer, amikor velem volt terhes, anyámat is befektették ebbe a kórházba, a házunktól alig száz méterre, ennél messzebbre nem is vihették volna, mert veszélyeztetettnek nyilvánították, a szülésig bent akarták tartani. Még le sem fektették, mesélte, neki már a szökésen járt az esze. Az intézmény ugyani mindkét irányban zárva volt: se a hozzátartozók nem mehettek be a szülő nőkhöz és az újszülöttekhez, se a nők sem mehettek ki a férjeikhez és családjukhoz. A megjelent etnikumok életvitelét ugyanis nem tartották kellően higiénikusnak, és féltek az átjárással bejutó fertőzésektől. Anyám szerint a hely minden elővigyázatosság ellenére is „egy koszfészek” volt, ráadásul köpcös, professzor apám se lett volna alkalmas arra, hogy átverekedje magát a tömegen a kerítés rácsáig, hogy szót váltson vele. Pedig annyi köztük a külföldi, jegyeztem meg a magam kilenc éves fejével, biztos nem érezte volna magát egyedül.

Ezt elsőre nem tudta hova tenni. Egyrészt, mert addigra magyar anyám sem tartotta már magát olyan nagyon külföldinek Bulgáriában, másrészt nem értette, hogy a törökül és cigányul kiabáló kispapákra gondolok, akiket nem engedtek be az újszülöttjeikhez. Én meg úgy tudtam, hogy ebben az országban bolgárok élnek, akik pedig véletlenül nem azok, bolgárul beszélnek, mint a cigányiskola tanulói a kerületi színjátszó vetélkedőn.

Anyámnak végül sikerült elszöknie, én pedig megszülettem egy budapesti kórházban, ahova az összes felmenőmet beengedték fényképezkedni a csecsemővel. Így emlékeztek rá utólag. Én pedig kilenc évesen szembesülhettem először azzal a sajátos multikulturalizmussal, aminek következtében anyám Pestig menekült megszülni engem. Ma ez az emlék értékes leletté lépett elő: az utolsó pillanatok egyikét kaptam el, amikor Bulgáriában még mindenki szabadon használhatta nyilvános helyen az anyanyelvét. Amikor a nyolcvanas évek közepén újra visszatértem Plovdivba, ennek már nyomát sem lehetett látni, hallani: helyszíni bírság fenyegetett mindenkit, aki az utcán kisebbségi anyanyelvén megszólalt. Azután 1989-ben minden megváltozott, de az ilyesmi nem múlik el nyomtalanul.

\section{Emlékezet és hajlékony hagyomány: a kulturális fóváros}

Plovdiv idén január óta Európa kulturális fövárosa. A hivatalos megnyitón a beszédek és a giccscsel kacérkodó kultúrműsor a város multikulturális hagyományait igyekezett kidomborítani, nyilván valami olyasmit akart sugallni, hogy odaát van a népek Európája, itt viszont Európa második legrégebbi városa, mely évezredek óta a népek Plovdivja. Fennkölt gondolat, büszkén vállalt hagyomány. Csakhogy a hagyomány legalább annyira manipulatív, mint az emlékezet. Erősen szelektív, és mindig a jelenlegi igényekből indul ki: hozzáidomul a mostani önképhez, ugyanakkor tompít mindent, ami ebbe nem fér bele. A viszonylag későn megkonstruált 
identitással induló közép- és kelet-európai kis nemzetek és államok (mondjuk így: nemzetállamok) a mai napig ebből gyúrják az „emlékezetpolitikájukat”, mely alkalomról alkalomra újrarendezi a hagyományt, és ha valami hagyomány, akkor ez az állandó átrendezés a legstabilabb eleme. A (Harari szerint) esetleges emlékezethez hozzárendelik a sanda természetű politikát, és máris kész egy új múlt, amivel nem kell szembenézni, elég csak azonosulni vele. Ez egy sajátos kommunikációs bűvészmutatványban, a kettős beszédben ölt testet: a kibocsátó látszólag egy üzenetet küld, de ez kétféleképpen is dekódolható, attól függően, hogy „külso””, vagy „belso”” befogadó értelmezi-e. Ezt elég rafináltan műveljük Közép- és Kelet-Európában, lehetne erre magyar, szerb, török, román, vagy akár orosz példát felhozni számosat. A Plovdiv - Európai kulturális fóváros show, nyilván, hazai és kinti közönségnek egyszerre szólt, nem véletlen gesztus, hogy külföldi látványtervező csoport tervezte a keretet (pedig náluk világszerte sikeresebb bolgár csapatok is lennének), és helyi művészeti iskolások és előadóművészek performálták. Kifelé a „népek Plovdivja” imázs azt üzeni, hogy ennél méltóbb helyre nem is kerülhetett volna a rangos esemény, a hely nem érdemtelenül rendezheti a fesztivált. És ennek az üzenetnek a külső befogadója örül, átszellemülten nézi a folkisch gagyit, amit a bolgár „küldo”” sugároz felé, mert elhiszi, hogy ezzel a saját ábrándjait kapja meg tőle. Befelé viszont azt sugallja az üzenet, ha mégoly óvatosan is, hogy Európa ma olyan elveket és erényeket hirdet a multikulturalizmussal, amelyeket mi itt évezredek óta gyakorolunk, bennünket nincs mire okítania, inkább fedezze fel nálunk a saját gyökereit. És ez büszkeséggel tölti el a helyi közönséget, hiszen a folkisch giccsben meg-megcsillan számára a balkáni és plovdivi multikulturalizmus ősi erénye, Európa pedig csak a saját hagyományainkat tükrözi vissza. És nincs is ezzel semmi baj, ha elhisszük, hogy európaibbak vagyunk az európaiaknál, csak ehhez sokat kell felejtenünk. És még többet hinnünk.

\section{Emlékezet és leletek}

A hitnek, feledésnek és emlékezésnek lehet valamiféle térben és időben alakuló dinamikája. Emlékszem, a hetvenes évek legelején lehetett, talán tíz évesen a város túlsó végére jártam angolra. Akkor még senkiben sem merült fel, hogy egy ennyi idős gyerek nem mászkálhat egyedül az utcán - ismertem az utat, miért ne mehettem volna? Útközben végig egy kavicsot rugdostam végig a járdán, háztól házig. Egyszer elvesztettem az eredeti kavicsot, egy építkezés mellett elém került egy cserépdarab, azzal folytattam. Szokatlan alakja volt, felvettem, és magammal vittem. Pár nappal később megmutattam apám egyik tudós barátjának, aki megnézte, és azt mondta, feltehetően római kori, valami motívumot fedezett fel rajta. Az ilyen törmelék halmokban áll a munkagödör mellett, mondtam, de ő rálegyintett: itt bárhol leásol pár métert, találsz valami régiséget, nem nagy ügy. Szó szerint vettem, és a magányos nyári napjaimban elkezdem túrni a földet a hátsó kertben. Találtam is egy márványból faragott, jókora mosdótálat, a ház alapozásakor kerülhetett a felszínre, majd a hátul elásták a többi törmelékkel együtt. Sosem derült ki, mikori (vajon mikor faraghattak márványból mosdótálat?), de kényelmes trónszékké alakítottam magamnak, melyet rengeteg játékhoz fel tudtunk használni a környékbeli szezonális utcagyerekekkel.

Egészen a hetvenes évek második feléig úgy építették a szocialista nagyvárost, hogy eltekintettek a múltjától. Ezekre az ókori-középkori emlékekre talán nem is volt szüksége a városnak, elvolt nélkülük. Elég volt tudni (vagy hinni), hogy itt emberemlékezet óta élnek, hiszen vétek lett volna egy ilyen remek, dombos-folyós helyet lakatlanul hagyni. Az Oszmán birodalom épített nyomait nagyrészt hagyták széthullani, meghagyták Európa egyik legnagyobb és legszebb mecsetét, a Dzsumaja Dzsámit, a török temető helyén európai típusú parkot létesítettek, a konakot átalakították francia líceummá. A nevezetes Vörös teret körbeépítették középületekkel, a környékén új lakónegyedeket húztak fel (egy ilyen mellől szedtem össze az első cserepemet) úgy, hogy feltehetően leküzdendő akadálynak tekintették az felszínre kerülő falakat és egyéb maradványokat. Aztán a hetvenes évek közepére hirtelen fontosak lettek a romok, a város központja tele lett körbebetonozott gödrökkel, a sétálóutca túlvégén még kávézót is berendeztek egy föld alól előkerült amfiteátrumban, később az egyik központi sugárutat emelték a levegőbe, hogy az alatta talált leletek hozzáférhetők legyenek a közönség számára. Egyedülálló szentélyek, templomok és kripták váltak látogathatóvá, az óváros dombjának oldalában feltárták a félsziget egyik leglátványosabb amfiteátrumát, mely ma is szabadtéri színpadként müködik. Gyerekkoromban ezeknek nem csak nyomuk sem volt, nem is sejtették, hogy valaha léteztek. Látszólag esetleges, véletlenszerűen előkerülő emlékek. Olyan 
korokból, melyekről tudtuk, hogy léteztek, de nem tudtuk, hogyan, mert semmit sem láttunk belőlük, mintha a történelem akkor kezdődött volna el, amikor elkezdték leírni, és azzal, amit leírtak. Annak a kornak az embere viszont, amelyik elkezdte fontosnak tekinteni, megbecsülni és feltárni ezeket az emlékeket, nem pusztán a mintázott cserepekre, kövekre, utakra, falakra és mozaikokra vágyott, hanem egy új identitás építőkockáit látta bennük: egy olyan önazonosságot, mely átnyúl a szocialista embertípus osztálytudatának feje fölött, és a múltból próbálja újrakonstruálni a jelenét - ennek minden áldott és átkozott következményével együtt.

\section{Emlékek és történészek}

A közép- és újkori utazók, visszaemlékezők, történetírók és történészek szövegei arról tanúskodnak, hogy Plovdivnak rengetegféle múltja van, ami szinte kimeríthetetlen forrása a lehetséges hagyományoknak és identitásoknak. A kulturális fóvárost megnyitó show-ban előadott multikulturális hagyomány is igazolható ezekből a szövegekből, amennyiben egy soknemzetiségű és sok vallású, mai fogalmaink szerint toleráns birodalmi város működését minden áron multikulturálisnak akarjuk látni. A 19. században két lépcsőben létrejövő mai bolgár nemzetállam nacionalista ideológiája azonban minden intézkedésével és intézményével ellene dolgozott annak, amit egy multikulturális város eszményképének nevezhetünk, ahol az egyes közösségek „heteroglosszái” folyamatosan kapcsolatban állnak egymással, versengenek, együttmüködnek, újradefiniálják, vagy alakítják egymást. Ez Alekszandar Kjoszev Plovdivról szóló alapos tanulmányának egyik fontos következtetése, aki azt is megállapítja, hogy nemzeti újjászületés korában (19. sz. második harmadától) Plovdiv, és általában Kelet-Rumélia, ahogy akkoriban a mai Dél-Bulgáriát nevezték, nem fért bele a nemzetépítők és -ébresztők látomásába, mert hiányozott belőle mindaz, ami elkötelezetten és tisztán bolgárrá tette volna mind életvitelében, mind szemléletében és műveltségében. Pedig többen megpróbálták a történelem során „bolgár nemzeti újjászületés bölcsőjének” is nevezni a várost, hiszen tényleg tevékenykedtek itt „nemzeti felvilágosítók”, de a közeg egésze mégis idegen volt a tiszta nemzeti ideálok megvalósításához. És valóban ezt a viszolygást a várossal szemben máig éreztetik a plovdiviakkal; máig megkapom Bulgária különböző szegleteiben, viccesen, vagy félig komolyan: mit vagy olyan nagyra azzal a „nyárspolgári” várossal. Pedig hát ez volt a mai Bulgária területének legfontosabb városa, gondoltam én, vallottuk mi mind, plovdiviak, akik hittünk a múltunkban, hiszen ezt a települést emlegetik ősidők óta a legsürübben a történészek és utazók, ennek szépségét magasztalták, főleg azzal az útszéli porfészekkel, Szófiával szemben.

Ez jól hangzik ugyan, de több benne a pökhendiség, mint az igazság. Közelebbről megvizsgálva talán ezúttal is az esetleges szóval lehetne a legárnyaltabban jellemezni Plovdiv szerepének és jelentőségének megjelenését a mediterrán - balkáni - közép- és kelet-európai térség legfontosabb történészeinek munkáiban. Hogy a végéről kezdjem: Maria Todorova mérföldkőnek számító Elképzelni a Balkánt címủ könyvében például Plovdiv neve egyszer sem szerepel. Talán az orosz-brit Dmitrij Obolensky megkerülhetetlen középkori Kelet-Európa történetében (A bizánci nemzetközösség) említi a legtöbbször a korabeli Philippopolis-t (ahogy a görögök nevezték), de a városról magáról keveset mond, inkább a Konstantinápolyba vezető úton elfoglalt stratégiai szerepéről, illetve a város környékén terjedő pauliciánus eretnekségről ír. A másik meghatározó régiótörténész, Fernand Braudel $A$ Földközi-tenger és a mediterrán világ II. Fülöp korában című háromkötetes munkájában talán ha kétszer említi a várost, akkor is abban a kontextusban, hogy ennek környékéről látják el rizzsel Isztambult. Ezt a tézist az amúgy alapos tudós feltehetően (mert jelöletlenül) a 17. századi híres török írótól és utazótól, Evlia Celebitől kölcsönözhette, lévén útirajzában ő értekezik kimerítően a város környéki mocsarakban termesztett kiváló minőségű (vöröses) rizsről, mely akár az egész főváros szükségleteit is ki tudná elégíteni. Braudel egyik legkiválóbb tanítványa, a macedón születésű, szerb-amerikai Traian Stoianovich a Balkáni világok. Az elsö és utolsó Európa címủ nagyszabású társadalomtörténeti áttekintésében több helyen is említi Philippopolis-t és Pulpudevát (ahogy a kelta-trákok nevezték), de gyakran bonyolódik nyelvészeti és őstörténeti spekulációkba, melyek felett jól érzékelhetően a szerb földrajz és történelemtudomány egyik legnagyobb hatású szerzőjének, Jovan Cvijicsnek a szelleme lebeg, igaz, a Cvijicsre jellemző kétértelmü tendenciózusság Stoianovich-tól meglehetősen távol áll. Cvijics ugyanis a tudósoknak ahhoz a fajtájához tartozott, akik szerették szaktudományos ismereteiket a politikai vízióikkal vegyíteni, ami óhatatlanul együtt járt azzal, hogy a látomásaik visszahatottak 
a következtetéseikre. A „humángeográfia” ürügyén Cvijics sokat emlegeti Plovdivot és környékét, élesen szembeállítva Szófiával és a mai Észak-Bulgáriával a néplélektan és az etnogenézis (értve ezen különböző népcsoportok keveredését) szempontjaira hivatkozva. Az első világháborút lezáró Párizsi békekonferencián a szerb küldöttség tagjaként a saját maga által generált „humángeográfiai tényekkel” érvelt, amikor az első Jugoszlávia határairól döntöttek, és ennek alapján például a Szófia környéki etnikailag „tisztán szláv” népességet (sopi) Jugoszlávia kebelére ölelte volna, a kun, besenyö, vlah és föleg görög géneket ötvöző plovdiviakat viszont meghagyta volna bolgárnak.

Nehéz eldönteni, akkor járunk-e jobban, ha egy történészt csak érintőlegesen érdekel egy város, vagy akkor, amikor nagyon, ellenben tendenciózusan. Abban Cvijicsnek mindenesetre igaza van, és ezt részben konkrétan Plovdivra is vonatkoztatja, hogy a Balkánon a civilizáció nem írható le folyamatként, az állandó bevándorlási és rombolási hullámok során csak azok a (síkföldi) városok épültek fel újra és újra, melyeken áthaladtak a fontos kereskedelmi útvonalak - de ezek a városok már alig őriztek meg valamit az előzők hagyatékából: új lakosság töltötte fel őket, mint ahogy a szerb történész szerint Plovdivot is lassan feltöltötték a Balkán-hegység településeiről aláereszkedő, kiskereskedő és kézműves bolgárok az 1870-es évek második felétől. És őket hidegen hagyták a város addigi polgárainak emlékei és hagyományai, s ez később, a 20. század elő évtizedétől, a dohány és könnyüipar beindulásával, a Macedóniából érkező, parasztból városi proletárrá alakuló hatalmas, dühös és gyökértelen tömeg esetében még ennél is fokozottabban érvényes.

Cvijics ezzel technikailag megválaszolja a kérdést: az emlékezés és leírás nyilván megtörik ott, ahol a történelmi folyamatosság ennyire szakadozott. A hely, amelyiknek nincs rögzített, folyamatosan "frissített” hagyománya, roppant jó nyersanyag a történészeknek, akik saját ábrándjaik táplálásához találhatnak muníciót az egymásba gabalyodó, elvesző, majd egy-egy elbeszélésben, régészeti leletben újra feltűnő korokban. Braudel a II. Fülöp kori mediterrán világban (benne, nyilván Plovdivval) meglátta az egységes Európa előképét; Stoianovich, aki - mint könyve alcíme is mutatja - a Balkánon, sejthetően inkább Jugoszláviában kereste az uniós Európa eszméinek az ősi gyökereit; Obolensky, aki - könyvének címéből is következően - közvetlenül a második világháború után a bizánci állam mechanizmusaiba talált rá egy birodalmi nemzetközösség (alighanem a britre gondolhatott) működésének kulcsára, s erre példaként épp azt hozza fel, ahogy a bizánci hatalom a Plovdiv környéki eretnekeket lerendezte; végül Cvijics, akit minden érdeme ellenére mára menthetetlenül etnocentristaként olvasunk, hiszen akadémiai tekintélyét arra használta fel, hogy becsatornázza saját államába a genetikailag (jugo)szláv bolgárokat, míg a Plovdiv környéki "crni bugarit" (fekete bolgárokat, ahogy ö maga is nevezi a könyvében) meghagyná egy másik országnak. Azon kevesek pedig, akik kilépnek a történelmi vizionálás köréből, és a városról/térségről szóló elbeszéléseket (narratívákat) kezdik el szálazni, mint például az idézett Kjoszev, azok segítik ugyan a történelmi tisztánlátást, de következtetéseik - sarkítva, nyilván -, miszerint a nacionalizmus korában nem alakulhat ki multikulturális város - inkább nyilvánvaló téziseket csomagolnak új érvekbe.

\section{Emlékek és mintázatok}

Nehéz elszakadni attól a gondolattól, hogy a hagyomány részben egy „emlékezetpolitikai” akarat, részben pedig a történészek fantáziálásának eredménye. Maria Todorova említett könyvében tesz egy javaslatot ennek meghaladására, ami már jelentősen túllép Cvijics „technikai” magyarázatán. Todorova megkülönbözteti a hagyományt (tradition) az örökségtől (legacy): ennek a két fogalomnak a történelmi átértelmezésével próbálja megragadni azt, hogyan lehet - a lehetőségekhez mérten - tárgyilagosan meghatározni egy régiót, esetünkben egy töredezett történelmű várost. A hagyományt - nagy vonalakban - egyfajta tudatos választással hozza kapcsolatba, olyan dolgokra vonatkozik, melyekhez az emberek direkt visszanyúlnak, szándékos választás révén beépítenek a jelenükbe. A történelmi örökség - ebben az értelmezésben - az, amit az emberek akarvaakaratlan magukkal cipelnek a megelőző korokból, benne rejlik a dolgokhoz magukhoz való viszonyuk és dolgokról alkotott képzetekhez való viszonyuk egyaránt. „Ha így tekintjük, az örökség se el nem árulja a múltat, sem nem veti magát alá az aktív beavatkozásainak. Az örökséghez lehet vehemensen viszonyulni, vagy hanyagolhatja is az utókor, de mindez csak másodlagos folyamat." És Todorova szerint ez a lényegesebb elem: ezek a belülről működő, időbeli kontinuitást biztosító mintázatok, a valóságosnak és az elképzeltnek, a tényszerünek és a konstruáltnak az összjátéka határozhatja meg az 
adott területen zajló események kimenetelét, az arra adott emberi reakciókat.

Visszatérve az emlékezetre, Plovdiv és a hasonló töredezett történelmű városok és régiók esetében mintha ezek a mintázatok határoznák meg a róluk szóló emlékek tartalmát is. Ilyen sokszorosan átörökített mintázat - metafizikusabb hajlandóságúak nevezhetik akár sorsnak is - az, hogy Plovdiv krónikásai alig látnak mást a városban, mint saját rögeszméik megvalósításának terepét. A 12. század közepéről maradt fenn ennek egy meglehetősen radikális példája: Anna Komnéné, I. Alexiosz Komnénosz bizánci császár lánya, az igaz, ortodox hit elkötelezett harcosa, gyakorlatilag csak eretnekeket lát Philippopolisban és környékén, az elburjánzó bogumil és pauliciánus tévelygésnek tudja be a város hanyatlását, mely, megjegyzi, egykor erős és gyönyörű lehetett. Ez, mellesleg, szinte minden későbbi visszaemlékezés visszatérő motívuma, de magáról a fénykorról beszámoló szöveg mintha nem is maradt volna fenn. Az önéletrajzi ihletésủ Alexiádban Komnéné részletesen leírja, ahogy apja, amint hírét vette annak, hogy a kunok átkeltek a Dunán, hadai élén a mai Plovdiv környékére vonult, hogy ott várja be őket egy döntő ütközetre. Csakhogy a kunok valami miatt késtek, ezért a császár megpróbálta hasznossá tenni magát a holtidőben: belevágott a renitens hívők átnevelésébe. Lánya ennek módszertanára is részletesen kitér: hosszú felolvasásokat tartott az egybegyüjtött eretnekeknek helyesnek tekintett szerzők traktátusaiból, gazdag adományokkal és privilégiumokkal jutalmazta az áttérőket, engedélyezte nekik a nőági örökösödést, sőt, egy új városrészt építtetett fel a megtérőknek a Hebrosz, vagyis a Marica túlpartján. A legmegátalkodottabbakat ezzel szemben életfogytig bezáratta, hogy „haljanak meg saját bủneik terhe alatt”. Sajátos nemzetközösségi ábránd lehetett ez utólag visszagondolva, különös tekintettel arra, hogy ezeknek az eretnekeknek az őseit épp Alexiosz egyik császári előde telepítette át (feltehetően nem saját kérésükre) Örményország területéről, hogy Trákiában élő pajzsként védjék a barbár betörésektől a birodalmi fővárost. Ja, igen, a kunok végül nem jelentek meg, a hadjárat dicsősége a térítésre korlátozódott.

De igazságtalanság lenne az emlékezet csőlátását pusztán a középkori vallási bigottéria számlájára írni. Anna Komnéné után több mint hét évszázaddal szinte ugyanazok a mintázatok olvashatók ki a lengyel Michał Czajkowski (akit a törökök Mehmet Sadık Paşa néven tartanak számon) plovdivi visszaemlékezéseiből. A lengyel forradalmak és az emigráció egyik közismert személyisége visszaemlékezéseiben szintén alig vesz észre mást a városból, mint az ott élő pauliciánusokat. Az ő küldetése, a korai modernitás szellemében, immár nem valamiféle birodalmi, hanem vállaltan az etnikai, pánszláv nemzetközösség megvalósítása volt. A plovdivi katolikusokat ezért negyvenezer lengyel leszármazottjaként mutatja be, akik egy közelebbről meghatározatlan időpontban a rizstermesztés fellendítése okán vándoroltak be a térségbe Pawlik és Jan lelkészek vezetésével (ettől pavlikjan a helyi elnevezés), és ugyan elveszítették nyelvüket és szokásaikat, de leírása szerint megőrizték a korabeli lengyeleket is jellemző külsőt, rebellis karakterüket és hitüket. Egy másik részük, szerinte, felvette a mohamedán hitet, és belőlük lettek a pomákok (ma: mohamedán bolgárok), akik a katolikusokkal ellentétben megőrizték a nyelvüket, szokásaikat és mondáikat. Nehéz lenne rekonstruálni, mint tört meg ennek az erkölcsi és politikai kérdésekben anynyira tisztán látó, remek katonaembernek az emlékezete, de a szövege Plovdivra vonatkozó része müfajilag tényleg közelebb áll a fantasyhez, mint az útleíráshoz.

A megtört emlékezetek sorát hosszan lehet/lehetne folytatni. Talán még Jurij Venelin, elismert nyelvész és néprajzkutató, az első bolgár nyelvtan szerzőjének esetét érdemes említeni, aki Georgij Guca néven született egy kárpátaljai hucul családban, és megközelítően Czajkowskival egy időben járta a bolgárok földjét. A Plovdivról szóló bekezdései azért kulcsfontosságúak, mert megközelítően olyan soknemzetiségü közegként írja le őket, mint amilyen az akkori szűkebb pátriája, Kárpátalja lehetett a Habsburg birodalmon belül, és ebben ő a bolgároknak rendelte azt a szerepet, ami a huculoknak jutott osztályrészül szűkebb pátriájában: többször és hangsúlyozottan visszatér az etnikai identitásukat görögre cserélő, görög iskolába járó bolgárokra, akikből a görögök gúnyt űznek falusi származásuk miatt, a bolgár pauliciánusokat unitáriusoknak nevezi, véletlenül sem katolikusoknak, és összességében a birodalmi, vagyis politikai ellenség, a török csak a városi etnikai paletta egyik komponensként jelenik meg a szövegben, míg a görög, a kulturális és vallási elnyomó (az osztrák és magyar analógiákra most nem térnék ki) a nemzeti önérvényesítés fö kerékkötőjévé lép elő. Ez a fajta „hazabeszélés” Venelinnél a kettősbeszéd egyik korai alfaja - az lehetett Czajkowski esetében is, hiszen józan ember nem ír le nyomós ok nélkül ekkora sületlenségeket 
-, amit tovább cizellál teljesen „hucultalanított” nevének mimikrije: mindannyian valahol bolgárok, valahol plovdiviak vagyunk...

Minden jel szerint a legszívósabb „mintázatokat" a bölcs 17. századi író és hivatásos utazó, Evlia Celebi hagyta ránk. Leginkább is azért, mert hájjal kenegeti plovdivi lelkünket, amikor az amúgy tíz kötetes Utazások könyvében az európai Törökország legszebb városának nevezi Filibét (ahogy a törökök hívták), leírja fekvését, történetét, gazdagságát, virágzó kereskedelmét, etnikai összetételét és építészetét. Talán ő az egyetlen utazó, aki vette magának a fáradságot és felkaptatott a város tíz dombjának egyikére - ő tízet számol össze, amúgy hétnek mondják, de ennek inkább a Róma-asszociáció felkeltése lehet az oka, amúgy meg mindenki azt nevezi dombnak, amit annak lát -, a Sahat tepére, vagyis Óradombra. Stoianovich szerint itt állt az első köztéri óra a Balkán területén, s ebből nem nehéz levonni a következtetést, hogy ebben a városban élt a lakosság először a nyugati értelemben strukturált idő szerint (ez akkoriban Nyugaton is elvétve volt jellemző), ami olyan eltérő magatartási mintázatokat alakíthatott ki, melyek máig idegennek - pedánsnak, nyárspolgárinak stb. - hatottak a térség társadalmi környezetében. Szóval, ott állt Celebi az óra mellett a dombtetőn, és onnan számolta össze az ólomlemezekkel lefedett házakat, a kúriákat és palotákat, ahogy ő nevezi a nagyobb építményeket, az etnikailag elkülönülő városrészeket, piacokat: röviden egy valóságosan több dimenziós földrajzitársadalmi/etnikai-történeti-gazdasági képet fest egy városról, és nem saját lelki tájképét, otthonról hozott vívódásait, és ami a fö, nem a konfliktusokat és konfrontációkat vetíti ki egy útjába kerülő településre, mint keresztény előfutárai és utódai. A Pax Ottomanicát látja megtestesülni a szépséges és gazdag Filibében, a toleranciát és jólétet, amelyről az akkori keresztény-nyugati világ csak ábrándozott - amint erre finom utalást is tesz a szövegében a derék krónikás.

\section{Emlékek ábrázolói}

Ez a mai értelemben vett multikulturalizmussal kacérkodó idill készítette elő a terepet mindazoknak a mintázatoknak, melyek a béke és tolerancia, az európaiság és kulturáltság mostani állapotát hivatottak ábrázolni; ez a hivatalos narratíva, köré épül az emlékezetpolitika, a hagyomány. A hagyomány, vagyis amit a történetünkből aktuálisan láttatni akarunk, amire az emlékezetünk az adott pillanatban érzékeny, az megjelenik a filmekben. Kurzusfilmekben, lehetne mondani, de melyik film nem egy korszak diskurzusainak terméke - még az is, amelyik ezekkel direkt szembehelyezkedik. Az egykori multikulturális Plovdivról szól, ott játszódik Ivan Nicsev A világ vége után című 1998-as filmje, melynek zsidó főhőse kisgyerekként éli meg a háborút, majd szüleivel áttelepül Izraelbe, ahonnan a demokrácia beköszönte után visszatér, és találkozik egykori örmény osztálytársnőjével, szerelmével, akinek a családját nem engedték annak idején Franciaországba emigrálni, helyette apját munkatáborba zárták. A gyerekkor egyfajta multikulturális eszményképként jelenik meg, ahol cigány és zsidó, örmény, bolgár és török gyerek együtt rosszalkodik, a három felekezet papjai együtt kocsmáznak és meg se lennének egymás nélkül. Aztán jönnek a kommunisták, és felszámolják a város sokszínüségét, a zsidókat elűzik, a görögöket tönkreteszik, az örményeket lecsukják, a cigányok „engedély nélkül épített" házait lerombolják: ez utóbbi a film valóban szívbemarkoló jelenete, fóleg amiatt, mert felvehették volna élőben akár az „érett szocializmus” időszakában, 1978-ban, amikor a Csocsoglu néven ismert katonai csúcsvezető unokaöccse meggyilkolása miatt bevezényelt egy páncélos hadosztályt a plovdivi Sztolipinovo cigánynegyedbe, majd évekig kitiltották a romákat a belvárosból; vagy még napjainkban is, amikor felelős politikusok valamilyen vélt, vagy valós bűncselekményért egy teljes közösséget bűnösnek kiáltanak ki, és lerombolják a viskóikat (legutóbb 2019 elején). A deviancia kollektív üldözése, alighanem, szintén olyan „örökség”, mintázat, amit a civilizációs folyamatok érintetlenül hagytak.

A film története, mely egy működőképes multikulturális közösség szétfogácsolódását mutatja be a represszív államszocializmusban, majd végső széthullást a vadkapitalizmus zsarnoksága alatt, bevallottan saját emlékekből táplálkozik, hiszen a föszereplő zsidó kisfiú szülei jiddis akcentussal beszélik a bolgárt, nem pedig a helyi zsidóság ladino (középkori spanyol) nyelvét keverik bele. Anzsel Vagenstajn, a forgatókönyv szerzője ezzel, nyilván, saját családjára, gyerekkorára utal, a közös európai nemzethez való csatlakozás előtt ilyen színezetet kaptak a plovdivi emlékei. Csakhogy érdemes belenézni az 1984-ben forgatott olasz dokumentumfilmbe, melyet egy olasz rendező, Giacomo Pezzali forgatott bolgár stábbal az Európa kulturális fơvárosai sorozat részekét. A film a felbecsülhetetlen dokumentum-felvételek ellenére meglehetősen 
vontatott, helyenként kínosan szimbolikus, művészet- és kultúraszemlélete még a rezsimhez és korhoz képest is kőkonzervatív. Az összekötő szöveget ugyanaz az Anzsel Vagenstajn írta, aki később a plovdivi multikulturális álmot elsiratta az 1998-as filmben. Csakhogy itt erről szó sem esik, az emlékek megtörnek az éppen aktuális érvényben lévő államszocialista patriotizmuson, és Plovdiv nemzetiségeiről, multikulturalizmusáról szó sem esik, ellenben úgy konferálja fel a települést, mint „mindenek előtt a nemzeti újjászületés városa”. Mi másról is szólhattak volna az emlékek abban az évben, amikor Bulgária kormánya megfosztotta alapvető emberi jogaitól lakosságának mintegy tíz százalékát, keresztény neve felvételére kötelezte török, pomák és roma állampolgárait, és szankcionálta anyanyelvük használatát nyilvános helyeken?

\section{Államszocialista emlékek}

$\mathrm{Az}$ államszocializmus amúgyis a legnagyobb emléktörőnek bizonyult. Miközben gyerekkori emlékeim nyomát kerestem a visszaemlékezésekben és a legnagyobb közös archívumában, az interneten, alig néhányra találtam utalást, szinte nem találtam társat a közös emlékezéshez. Albena Skodrova Szocgurmé. A Bolgár Népköztársaság konyhájának története címü társadalomtörténeti monográfia üde kivétel: ebből hitelesen visszaköszönt a hetvenes évek hiánygazdasága, a hervasztó kínálat és a napi küzdelem a minőségi élelmiszerért, a „mintaboltokban” és valutás üzletekben beszerezhető árucikkek leplezetlen pártállami cinizmusa, a szánalmas közétkeztetés és a gyatra vendéglátás.

Ezzel szemben a feltehetően Plovdiv-specifikus, pártállami kuriózumoknak alig bukkantam a nyomára a világhálón. Az 1976-os „kongresszusköszöntő kocogásról” csupán néhány fotót őrzött meg a plovdivi városi levéltár, azon is klottgatyás veteránok állnak a rajtvonalnál. Pedig világosan emlékszem, hogyan terelték ki a nagyszünetben a városi parkba az egész iskolánkat, ahol az igazgató futott elől, kereken 1976 métert, nekünk, kicsiknek csak 800 volt elöírva. Szerencsére ebben a parkban nőttem fel, ismertem minden átjárót a bokrok között, túlsúlyos kisgyerekként hordágyon vittek volna el, ha ennyit le kell futnom. A célban aztán lepecsételték az ellenőrző kartont, a megfelelő számú pecsétet be lehetett váltani egy kongresszusi futás feliratú pólóra. Otthon aztán szegény apám panaszkodott, hogy az egyetem kisz-titkára rátörte a dolgozószoba ajtaját, és ki akarta parancsolni őt is futni a többiekkel. Krasztev elvtárs elhajtotta ugyan a feltörekvő fiatalembert, mert úgy érezte, világhírű tudósként nem ezen fog múlni a további karrierje, de azért pár hónapig szorongott a várható következményektől. És akkor futott a város apraja-nagyja, szinte elképzelhetetlen, hogy nem maradt nyoma.

Mint ahogy annak sem jutottam a nyomára, mi volt az a köznyelvben 30/30-nak nevezett rendelet, ami miatt végül anyámnál betelt a pohár, és hazaszöktetett engem végleg Magyarországra. Az akkori direktíva a szabados életvitelt folytató és nyugatias külsőt öltő kiskorúak megregulázását irányozta elő, s utasításba adta, hogy bármelyik felnőttnek jogában áll saját hatáskörben elvinni és megnyíratni a megengedettnél hosszabb hajat viselő kiskorút, vagy a rendőrségre bevinni a dohányzáson kapott fiatalt, illetve elő́llítani az este kilenc után felügyelet nélkül kint tartózkodó gyereket. Szinte hetente tartottak frizuraellenőrzést az iskolabejáratnál: volt, hogy az igazgató személyesen állt a bejáratnál, túrt bele minden fiú hajába, és akié túlnőtt a kérges ujjain, azt visszaküldte nyiratkozni - nyilván, halmazati büntetésként igazolatlan hiányzás is járt vele. Sosem felejtem el, ahogy a megaláztatástól zokogva kárhoztattam szerencsétlen anyámat, hogy nem vette észre, mennyire megnőtt a hajam, ráadásul tíz évesen egy fillér sem volt a zsebemben, amivel a borbélyt kifizethettem volna.

Mire a kongresszusi futás piros pólóját megküldték, már Magyarországon éltem, amikor eljutott hozzám, már nem is ment rám, a hajamhoz pedig két évig nem engedtem hozzányúlni...

És, persze, vannak alaposabban dokumentált emlékek is, például a vásárok. A nemzetközi vásárokról később kiváló elemző tanulmányok születtek, magáról a jelenségről, hogy a Nyugatot beengedték ennyire mélyen az államszocializmus ideológiai frontvonala mögé. Mary Neuburger szellemes Kebabcse, kaviár, vagy hotdog? A hidegháború fogyasztása a plovdivi vásáron 1947-72 címü tanulmányát szintén egy külföldi, történetesen brit résztvevő visszaemlékezéseire alapozza, s a szövegéből meggyözen kimutatja, mennyire „megtörtek” plovdivi emlékei a korabeli Kelet-Nyugat kliséken. Gyerekként szinte minden nap ott lógtunk a pavilonok között, semmit sem értettünk a kiállított műszaki csodákból, de azért megéreztük a varázslatot a vásárváros utcáin lassan surranó, fényes amerikai limuzinban, a kiállított jachtban és Harley Davidsonban; gyűjtöttünk minden nyugati brosúrát, jelvényt és egyéb kacatot, átszellemülten szagolgattuk 
a fényes, színes nyomtatványokat, cserélgettük egymás között a zsákmányt, de kár lenne tagadni, hogy legalább ugyanakkor áhítattal bámultuk a szovjet kiállítás életnagyságú űrmakettjeit, bumfordi háztartási és híradástechnikai eszközeit, miközben szüleink belevették magukat a korabeli konzumőrületbe, mert erre a pár hétre - a számos külföldi vendégre való tekintettel - végre feltöltötték áruval a városközpont üzleteit, lehetett normális cipőt és ruhát is vásárolni, olíva olajat is egy évre előre, és teszt jelleggel olyan új termékek is forgalomba kerültek, melyeket a vásár bolgár pavilonjában akkor mutattak be, hogy aztán végleg és visszavonhatatlanul elnyelje őket a feledés enyészete.

Extrém ideológiai keménykedés és lohasztó hiánygazdálkodás, majd egy éles váltással nyitás a Nyugatra, fellazulás és mesés árukínálat: számomra máig rejtély, hogy bírta ezt a kontrasztot ilyen beletörődéssel viselni egy város lakossága. Hacsak nincs valami lappangó örökség, vagy „mintázat”, ami immunissá teszi a plovdiviakat az efféle kettősségekkel szemben.

\section{Záró emlék-képek}

Plovdivi emlékeim egy gyerek emlékei: képek a szüleimről, egy városról és a lakóiról. Emlékképek anyám heroikus küzdelméről a hétköznapi túlélésért, elvágyódásáról egy komfortosabb világba, apám tudományba, fóleg saját tudományába vetett hitéről és közönyéről minden más iránt, tudós barátaikról, akik közül időnként egyik-másiknak átmenetileg nyoma veszett, egy úgymond, „politikai vicc” miatt; alsós tanárnőm mérhetetlen elhivatottságáról és felsős tanáraim megátalkodott fafejüségéről; a gyerekfejjel is elviselhetetlen posztsztálinista hivatalos légkörről, és a felszabadult szünidei bandázásról a városban, amihez hasonló Budapesten akkoriban már elképzelhetetlen lett volna, az első életre szóló barátokról és gyerekszerelmekről, akiket mára mind elveszítettem szem elől; a város akkori figuráiról, akik az én hétköznapjaim szereplői is voltak: Miljóról, a városi bolondról (hál'isten azóta kapott köztéri szobrot), a hintázó járású és beszólogató jampecekről, a kontinens legszebb utcáját minden éjszaka végig gajdoló korhelyekről, a feltaláló csodabogarakról, mint Ico Ikara (Ikarusz Ico), aki egy VAZ 21011/1300 motorból és Wartburg lökhárítóból felépített egy versenyautót, aminek az egész város a csodájára járt, mégsem versenyzett vele soha senki; Jankóról, a meleg takarítóról, akit úton-útfélen megvertek, mégis folyton mosolygott és énekelt...

Csak idő kérdése, hogy összeszedjek még néhány oldalnyi apró, lényeges és mellékes részletet, mely egytől-egyig legalább annyira esetleges, mint a születésem helyszíne, vagy a találomra felszedett agyagcserép: emlékek, melyek megtörnek egy átlagosan boldog gyerekkor és egy nyomasztó önkényuralom peremén, amitől értelmet nyernek, és talán értelmet tudnak adni régi és újabb korok más emlékeinek, melyek szintén megtörtek szerzőik életútjának bukkanóin, ha magát a várost nem is értelmezi, mert egy városnak mi más értelme lenne, mint hogy lakjunk és jól érezzük magukat benne. Vagy esetleg olyanná tegyen bennünket, amilyenek vagyunk.

\section{Felhasznált szakirodalom}

Braudel, Fernand 1995 The Mediterranean and the Mediterranean World in the Age of Philip II. University of California Press.

Цвијић, Јован 1922 Балканско полуострво и јужнословенске земље. Основи антропогеографије 1-2. Belgrád.

Harari, Yuval 2016 Homo Deus. A holnap rövid története. Animus Kiadó, Budapest. https:// www.scribd.com/document/388452601/ Homo-Deus-Harari-Yuval-Noah-pdf

Kiossev, Aleksander 2004 Plovdiv: The Text of the City vs. the Texts of Literature. In Marcel Cornis-Pope - John Neubauer szerk. History of the Literary Cultures of East-Central Europe. Vol 2. John Benjamins, Amsterdam.

Neuburger, Mary 2012 Kebabche, Caviar or Hot Dogs? Consuming the Cold War at the Plovdiv Fair 1947-72. Journal of Contemporary History 47(1):48-68. https://doi. org/10.1177/0022009411422368 https:// www.jstor.org/stable/23248981

Obolensky, Dimitri 1974 Byzantine Commonwealth. Eastern Europe 500-1453. London, Cardinal.

Stoianovich, Traian 1994 Balkan Worlds. The First and Last Europe. Routledge, London - New York.

Todorova, Maria 1997 Imagining the Balkans. Oxford University Press. 


\section{On-line forráshivatkozások}

http://www.vostlit.info/Texts/Dokumenty/

Bulgarien/XIX/1820-1840/Venelin/

frametext1.htm

http://www.vostlit.info/Texts/Dokumenty/Turk/

XIX/1820-1840/Sadyk_pasa_2/text1.htm

https://www.rulit.me/books/aleksiada-

read-37025-186.html

http://plovdivskinovini.bg/komentari/137345/

spomeni-ot-sotza-prez-1978-g-po-zapoved-na-

chochoolu-tankove-gazyat-stolipinovo

https://trafficnews.bg/istoriya/spomeni-sotsa-

kogato-zhenite-minizhup-biaha-zozi-a-

mazhete-108667/

https://www.marica.bg/skelet-na-kyshta-plashisysedite-v-centyra-Article-111408.html

https://plovdivtime.bg/nasledstvo/

plovdiv-spomenite-evliia-chelebi-21/

http://www.archives.government.bg/183-\%D0\%9

F\%D0\%BB\%D0\%BE\%D0\%B2\%D0\%B4\%

D0\%B8\%D0\%B2\# 